\title{
Optimization of Storage Temperature for Cultured ARPE-19 Cells
}

\author{
Lara Pasovic, ${ }^{1}$ Tor Paaske Utheim, ${ }^{1,2,3}$ Rima Maria, ${ }^{1}$ Torstein Lyberg, ${ }^{1}$ Edward B. Messelt, ${ }^{4}$ \\ Peder Aabel, ${ }^{1,5}$ Dong Feng Chen, ${ }^{6}$ Xiangjun Chen, ${ }^{3}$ and Jon Roger Eidet ${ }^{1}$ \\ ${ }^{1}$ Department of Medical Biochemistry, Oslo University Hospital, Kirkeveien 166, P.O. Box 4956, Nydalen, 0424 Oslo, Norway \\ ${ }^{2}$ Department of Ophthalmology, Oslo University Hospital, Kirkeveien 166, P.O. Box 4956, Nydalen, 0424 Oslo, Norway \\ ${ }^{3}$ SynsLaser Kirurgi Oslo/Tromsø, Lille Grensen 7, 0159 Oslo, Norway \\ ${ }^{4}$ Department of Oral Biology, Faculty of Dentistry, University of Oslo, Sognsvannsveien 10, P.O. Box 1052, Blindern, 0316 Oslo, Norway \\ ${ }^{5}$ Division of Surgery, Ear, Nose and Throat Department, Akershus University Hospital, Sykehusveien 25, 1478 Lørenskog, Norway \\ ${ }^{6}$ Schepens Eye Research Institute, Department of Ophthalmology, Harvard Medical School, 20 Staniford Street, Boston, MA 02114, USA
}

Correspondence should be addressed to Lara Pasovic; larapasovic@gmail.com

Received 4 July 2013; Revised 2 September 2013; Accepted 3 September 2013

Academic Editor: Alfredo García-Layana

Copyright (C) 2013 Lara Pasovic et al. This is an open access article distributed under the Creative Commons Attribution License, which permits unrestricted use, distribution, and reproduction in any medium, provided the original work is properly cited.

\begin{abstract}
Purpose. The establishment of future retinal pigment epithelium (RPE) replacement therapy is partly dependent on the availability of tissue-engineered RPE cells, which may be enhanced by the development of suitable storage methods for RPE. This study investigates the effect of different storage temperatures on the viability, morphology, and phenotype of cultured RPE. Methods. ARPE-19 cells were cultured under standard conditions and stored in HEPES-buffered MEM at nine temperatures $\left(4^{\circ} \mathrm{C}, 8^{\circ} \mathrm{C}, 12^{\circ} \mathrm{C}\right.$, $16^{\circ} \mathrm{C}, 20^{\circ} \mathrm{C}, 24^{\circ} \mathrm{C}, 28^{\circ} \mathrm{C}, 32^{\circ} \mathrm{C}$, and $37^{\circ} \mathrm{C}$ ) for seven days. Viability and phenotype were assessed by a microplate fluorometer and epifluorescence microscopy, while morphology was analyzed by scanning electron microscopy. Results. The percentage of viable cells preserved after storage was highest in the $16^{\circ} \mathrm{C}$ group $\left(48.7 \% \pm 9.8 \% ; P<0.01\right.$ compared to $4^{\circ} \mathrm{C}, 8^{\circ} \mathrm{C}$, and $24^{\circ} \mathrm{C}-37^{\circ} \mathrm{C} ; \mathrm{P}<0.05$ compared to $12^{\circ} \mathrm{C}$ ). Ultrastructure was best preserved at $12^{\circ} \mathrm{C}, 16^{\circ} \mathrm{C}$, and $20^{\circ} \mathrm{C}$. Expression of actin, ZO-1, PCNA, caspase-3, and $\mathrm{RPE} 65$ was maintained after storage at $16^{\circ} \mathrm{C}$ compared to control cells that were not stored. Conclusion. Out of nine temperatures tested between $4^{\circ} \mathrm{C}$ and $37^{\circ} \mathrm{C}$, storage at $12^{\circ} \mathrm{C}, 16^{\circ} \mathrm{C}$, and $20^{\circ} \mathrm{C}$ was optimal for maintenance of RPE cell viability, morphology, and phenotype. The preservation of RPE cells is critically dependent on storage temperature.
\end{abstract}

\section{Introduction}

Dysfunction and loss of retinal pigment epithelium (RPE) are major pathological changes in retinal degenerative diseases such as age-related macular degeneration (AMD) and Stargardt disease. RPE cells have been shown to be good candidates for cell replacement therapy for these diseases [17]. With the demonstration of long-term survival of RPE cell transplants both in various animal models and in humans [813], transplantation offers the prospect of a single intervention cure. The transplantation of RPE grafts enables appropriate implantation and orientation of an organized RPE cell layer in the retina $[5,14,15]$ and circumvents several of the complications associated with the use of RPE cell suspensions $[6,8,15,16]$.
In corneal transplantation, the development of storage techniques has simplified surgery logistics, enabled quality control and tissue transportation, and provided worldwide tissue availability. With the advancement of RPE cell replacement therapy, and with 20-25 million known sufferers from AMD worldwide [17], a great need for improved storage methods for cultured RPE is likely to emerge. Due to strict regulatory demands $[18,19]$, the development of a suitable storage method will be essential to enable the transportation of viable cell constructs from centralized laboratories to operating theatres [18]. A short-term storage method would be sufficient for this purpose, but no such protocol is available, and the optimal temperature for the short-term storage of RPE cells has not been established. 
Based on previous publications on storage of cultured epithelial cells [20-23], we hypothesize that differences in storage temperature between $4^{\circ} \mathrm{C}$ and $37^{\circ} \mathrm{C}$ affect the viability, morphology, and phenotype of cultured RPE cells. In the current study, we have used the spontaneously immortalized ARPE-19 cell line as a model. Though widely used and appreciated for displaying significant functional differentiation $[24,25]$, this cell line does not mirror all the functions and characteristics of native RPE [26, 27]. To ensure that the cells used in our study differ as little from primary RPE as possible, we assessed their cytoskeletal, junctional, and differential properties.

\section{Materials and Methods}

2.1. Cell Culture Media and Reagents. Cells from the adult RPE cell line ARPE-19 were obtained from the American Type Culture Collection (ATCC) (Manassas, VA). Dulbecco's Modified Eagle's Medium (DMEM): Nutrient Mixture F12, fetal bovine serum (FBS), bovine serum albumin (BSA), trypsin-EDTA, 4-(2-hydroxyethyl)-1piperazineethanesulfonic acid (HEPES), sodium bicarbonate, gentamycin, phosphate-buffered saline (PBS), Triton X-100, penicillin, streptomycin, and $4^{\prime}, 6$-diamidino-2-phenylindole (DAPI) was provided by Sigma-Aldrich (St. Louis, MO). Nunclon $\Delta$-surface multidishes, glass coverslips, pipettes, and other routine plastics were supplied by VWR International (West Chester, PA). The minimum essential medium (MEM), calcein-acetoxymethyl ester (CAM), Alexa Fluor 568 phalloidin, and the primary mouse anti-ZO-1 antibody were purchased from Life Technologies (Carlsbad, CA). Staurosporine and the primary rabbit anti-cleaved caspase- 3 (Asp 175) antibody were obtained from Cell Signaling Technology (Danvers, MA). The primary mouse anti-RPE65 antibody and the secondary antibodies FITC conjugated to goat anti-mouse IgG and Cy3 conjugated to goat anti-rabbit IgG were all purchased from Abcam (Cambridge, UK), while the mouse anti-PCNA antibody was obtained from DAKO (Glostrup, Denmark).

2.2. Cell Culture. Adult human retinal pigment epithelial (ARPE-19) cells were routinely cultured in 95\% air and $5 \% \mathrm{CO}_{2}$ at $37^{\circ} \mathrm{C}$ in DMEM/F12 medium containing $10 \%$ FBS, 50 units $/ \mathrm{mL}$ penicillin, and $50 \mu \mathrm{g} / \mathrm{mL}$ streptomycin. The cells were seeded $\left(5000\right.$ cells $\left./ \mathrm{cm}^{2}\right)$ on Nunclon $\Delta$-surface multidishes and glass coverslips. The culture medium was changed on the second day, and confluent cultures were obtained on the third day. Control cultures, which were not subjected to subsequent storage, were then immediately processed for the various analyses.

2.3. Cell Storage and Equipment. After the three-day culture period, the multidishes were removed from the incubator, and the culture medium was replaced by storage medium consisting of $1 \mathrm{~mL}$ MEM, $25 \mathrm{mM}$ HEPES, $22.3 \mathrm{mM}$ sodium bicarbonate, and $50 \mu \mathrm{g} / \mathrm{mL}$ gentamycin. Thereafter, the cultures were randomized for storage at nine temperatures $\left(4^{\circ} \mathrm{C}, 8^{\circ} \mathrm{C}, 12^{\circ} \mathrm{C}, 16^{\circ} \mathrm{C}, 20^{\circ} \mathrm{C}, 24^{\circ} \mathrm{C}, 28^{\circ} \mathrm{C}, 32^{\circ} \mathrm{C}\right.$, and $\left.37^{\circ} \mathrm{C}\right)$ for

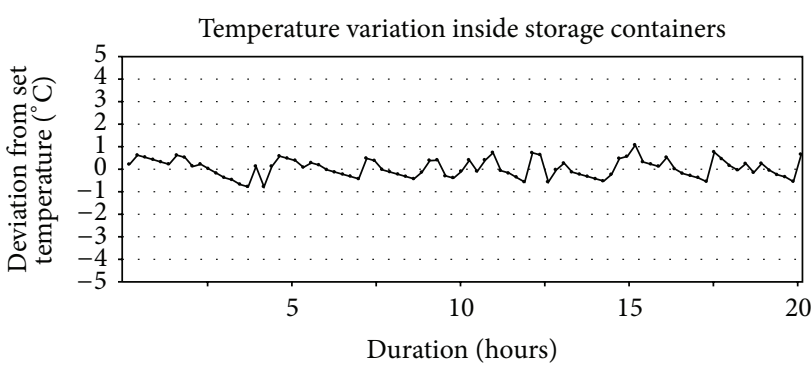

FIGURE 1: In a pilot study, the temperature inside seven of the storage containers was noted at 86 consecutive time points throughout 20 hours to assess the magnitude of the variation of the set temperature. The maximum deviation was -0.8 to $+1.0^{\circ} \mathrm{C}$.

seven days in custom-built storage containers without $\mathrm{CO}_{2}$ supply.

The storage containers were made from polystyrene and were kept in a cold room which maintained an ambient temperature below $4^{\circ} \mathrm{C}$. All containers were equipped with (1) an electronic temperature display that enabled control of the storage temperature inside each box; (2) a heater that increased the temperature inside the box from the ambient room temperature $\left(<4^{\circ} \mathrm{C}\right)$ to the desired storage temperature; (3) a highly sensitive thermometer that continuously regulated the heater; and (4) a small fan that ensured a homogeneous temperature inside the box by circulating the air. The stability of the temperature inside the storage containers was confirmed in a pilot study (Figure 1). In addition, the temperature inside each storage container was checked regularly throughout all experiments.

2.4. Viability Assessment. Viability after one week of storage was analyzed using CAM, which is enzymatically cleaved into the green fluorescent calcein inside living cells (Figure 2(a)) [28]. The cells were incubated for one hour in PBS containing $1 \mu \mathrm{M}$ CAM, and the CAM fluorescence was measured by a microplate fluorometer (Fluoroskan Ascent, Thermo Scientific, Waltham, MA) with the excitation/emission filter pair $485 \mathrm{~nm} / 538 \mathrm{~nm}\left(N=6\right.$ (repeated twice, 3 each) for $4^{\circ} \mathrm{C}$, $8^{\circ} \mathrm{C}$ and $24^{\circ} \mathrm{C}-37^{\circ} \mathrm{C}$; and $N=12$ (repeated four times, 3 each) for $12^{\circ} \mathrm{C}-20^{\circ} \mathrm{C}$ ). Three-day cultured cells that were not subjected to storage, but instead immediately analyzed with CAM, served as controls.

To determine the reliability of the CAM measurements obtained by the microplate reader, a standard curve was made. Using a cell counter (Scepter 2.0 Cell Counter, Merck Millipore; Billerica, MA), cell suspensions with increasing cell concentrations were seeded in multidishes and left for two hours to ensure cell attachment. The cells were then incubated with the CAM reagent as described above to stain the attached cells. The CAM fluorescence was thereafter measured by the microplate reader. The number of seeded cells correlated highly with the measured CAM fluorescence, thereby showing great accuracy of the microplate reader measurements (Pearson's $r=0.984 ; P<0.001$ ) (Figure 2(e)). 


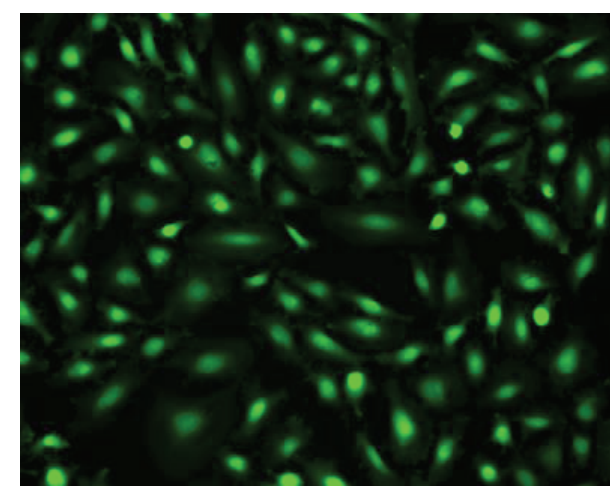

(a)

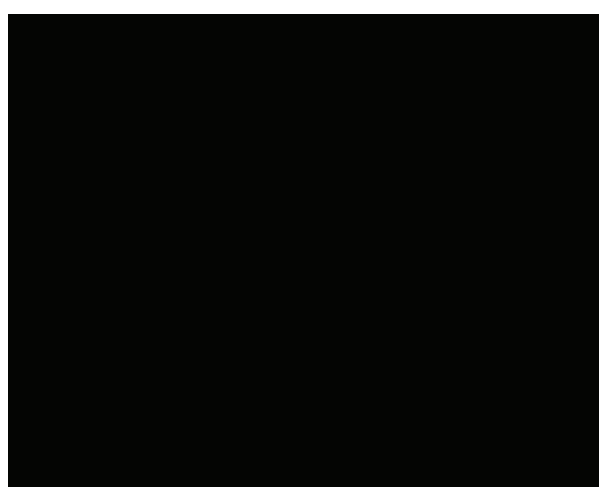

(c)

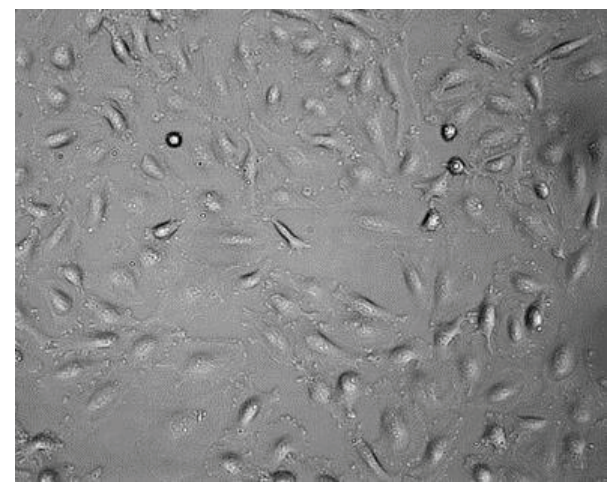

(b)

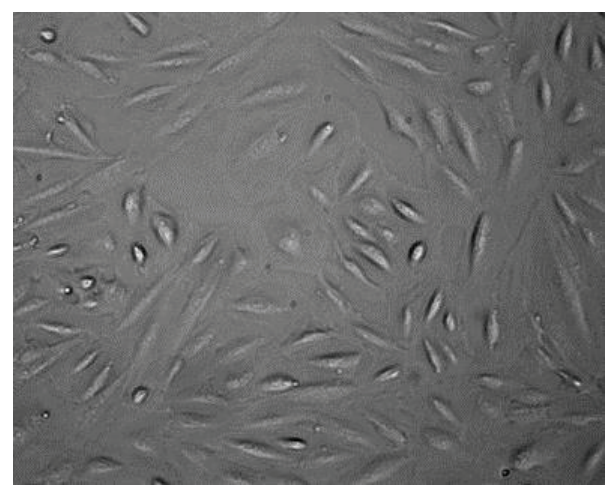

(d)

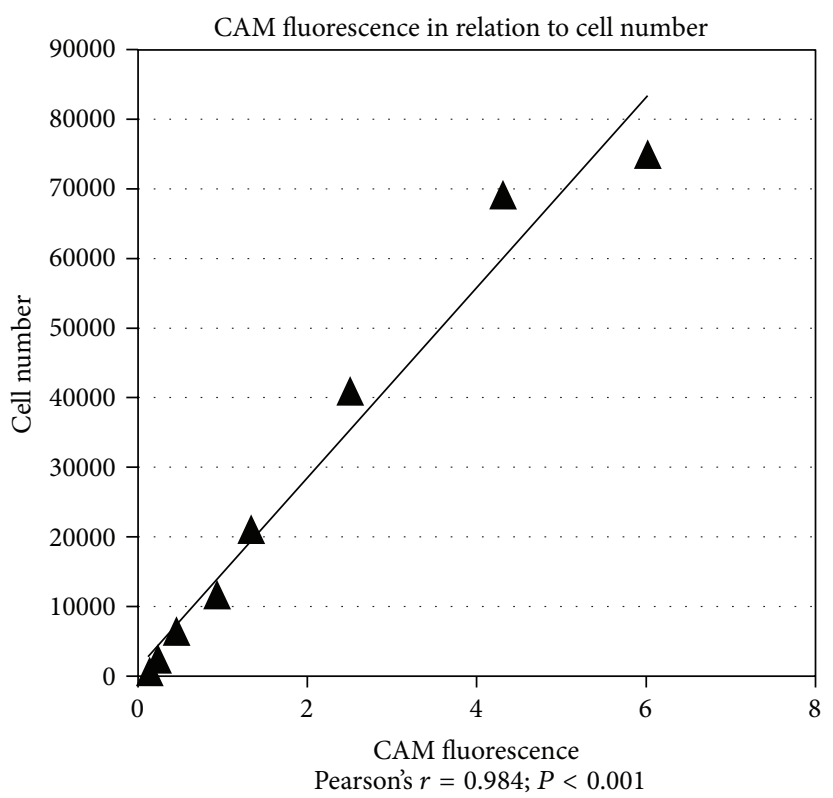

(e)

FIGURE 2: A calcein-acetoxymethyl ester (CAM) reagent, which exclusively stains living cells, was used to analyze cell survival. To validate the method, control cells and methanol-fixed cells were incubated with PBS containing $1 \mu \mathrm{M}$ CAM (green). (a) Control cells were CAM+ (green). (b) Corresponding phase contrast micrograph to (a). (c) Fixed cells were CAM-. (d) Corresponding phase contrast micrograph to (c). (e) Cells were seeded in multidishes in increasing concentrations and incubated for two hours to ensure attachment to the substrate. The CAM reagent was added to the cells for one hour, and the CAM fluorescence was measured with a microplate fluorometer. The number of seeded cells correlated significantly with the measured CAM fluorescence, thereby proving great accuracy of the microplate reader measurements. 
2.5. Morphology Analysis. ARPE-19 cells were cultured on glass coverslips, and the samples were stored at nine temperatures for seven days before being processed for scanning electron microscopy (SEM) as previously described $(N=8$ (repeated twice, 4 each) for $4^{\circ} \mathrm{C}, 8^{\circ} \mathrm{C}$, and $24^{\circ} \mathrm{C}-37^{\circ} \mathrm{C} ; \mathrm{N}=12$ (repeated three times, 4 each) for $12^{\circ} \mathrm{C}-20^{\circ} \mathrm{C}$ ) [29]. In brief, stored cultures were fixed in $2.5 \%$ glutaraldehyde solution, dehydrated in ethanol, and dried in compliance with the critical point method (Polaron E3100 Critical Point Drier; Polaron Equipment Ltd., Watford, UK). The control cultures were processed for SEM without delay after the three-day culture period. Coating of the samples with a $30 \mathrm{~nm}$ thick layer of platinum in a Polaron E5100 sputter coater was done prior to photographing with an XL30 ESEM electron microscope (Philips, Amsterdam, The Netherlands).

2.6. Phenotype Analysis. Cells were cultured in 24-well multidishes and stored at $12^{\circ} \mathrm{C}, 16^{\circ} \mathrm{C}$, and $20^{\circ} \mathrm{C}$ as described above. Samples were subsequently prepared for immunocytochemical characterization by 15 minutes of methanol fixation at room temperature followed by 30 minutes of permeabilization and blocking in PBS containing $1 \%$ BSA and $0.2 \%$ Triton X-100. Control cells were processed for immunocytochemistry immediately after the three-day culture period.

Anti-ZO-1 (1:50), anti-RPE65 (1:200), anti-PCNA $(1: 1000)$, and anti-cleaved caspase-3 $(1: 400)$ antibodies were diluted in blocking solution (PBS with $1 \%$ BSA). Primary antibodies were omitted from the negative controls. Samples were incubated overnight at $4^{\circ} \mathrm{C}$. Goat anti-mouse FITC-conjugated secondary antibodies (diluted 1:250 in blocking solution) and goat anti-rabbit $\mathrm{Cy} 3$-conjugated secondary antibodies (diluted 1:10000 in blocking solution) were added for one hour at room temperature. Specimens were washed three times in PBS, with the addition of $1 \mu \mathrm{g} / \mathrm{mL}$ DAPI during the last wash to stain the cell nuclei. Positive control cultures for caspase-3 included incubating cells with $1 \mu \mathrm{M}$ staurosporine for 24 hours (Figure 3 ). Treatment with staurosporine is expected to trigger expression of caspase- 3 and induce cell apoptosis [30].

To visualize the actin cytoskeleton, samples were fixed in $4 \%$ formaldehyde for 10 minutes, permeabilized with PBS containing $0.1 \%$ Triton-X, and stained with PBS containing $25 \mu \mathrm{L} / \mathrm{mL}$ Alexa Fluor 568 phalloidin methanolic stock solution. After incubating for 20 minutes in room temperature, specimens were washed in PBS and stained with DAPI.

The specimens were studied using a Nikon Eclipse $\mathrm{Ti}$ fluorescence microscope and photographed at $\times 200$ magnification with a DS-Qil black-and-white camera. Photomicrographs were captured at five predetermined positions in each culture using a motorized microscope stage. The exposure length and gain was maintained at a constant level for all samples, and the image brightness was within the dynamic range of the camera. Two blinded and independent investigators assessed expression of the various markers in five photomicrographs in each culture $(N=8$ (repeated twice, 4 each)). For the RPE65, PCNA, and caspase-3 markers, the number of positive cells/total number of cells $\times 100 \%$

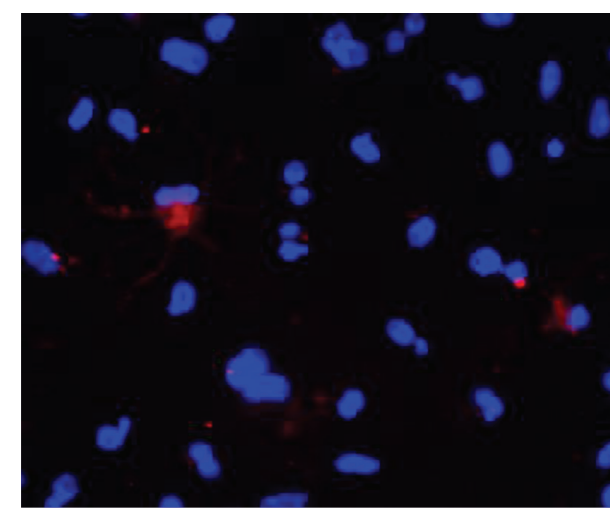

(a)

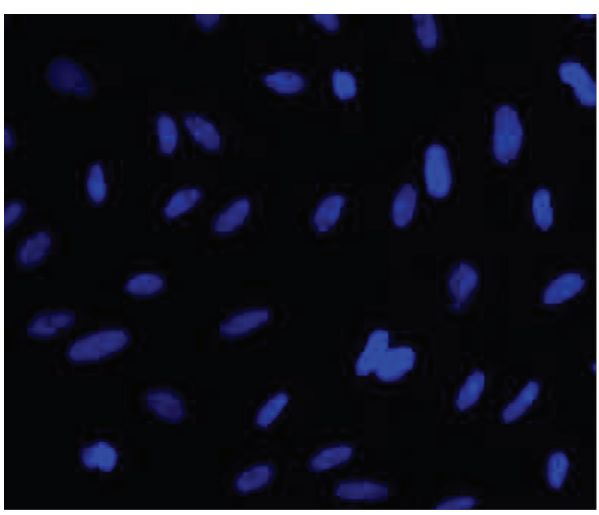

(b)

FIgURe 3: Positive control to the caspase-3 antibody. Cultured RPE cells were incubated with $1 \mu \mathrm{M}$ staurosporine for 24 hours in order to trigger expression of caspase- 3 and induce cell apoptosis. (a) Photomicrograph showing immunostaining of caspase-3 (red) in apoptotic cells treated with staurosporine. Nuclei were stained with DAPI (blue). Original magnification: $\times 200$. (b) Negative control showing only DAPI staining (blue) when no staurosporine is added. Original magnification: $\times 200$.

was calculated. Assessment of observer agreement between the two investigators demonstrated high reliability of the phenotypic data (Table 1).

2.7. Statistical Analysis. A one-way analysis of variance with Tukey's post hoc comparisons (SPSS ver. 19.0) was used for statistical evaluation of the results from the viability and phenotype analyses. Pearson's correlation and a paired sample Student's $t$-test were utilized to calculate observer agreement of the phenotype data. $P$ values below 0.05 were considered significant.

\section{Results}

3.1. Viability of Cultured ARPE-19 Cells following Storage. To study the impact of different temperatures on RPE cell survival, cell viability was analyzed using CAM. Sealed multidishes with ARPE-19 cell cultures were randomized for storage at $4^{\circ} \mathrm{C}, 8^{\circ} \mathrm{C}, 12^{\circ} \mathrm{C}, 16^{\circ} \mathrm{C}, 20^{\circ} \mathrm{C}, 24^{\circ} \mathrm{C}, 28^{\circ} \mathrm{C}, 32^{\circ} \mathrm{C}$, and $37^{\circ} \mathrm{C}$ for seven days. The number of live cells after seven days 
TABLE 1: Characterization of retinal pigment epithelial cells.

\begin{tabular}{|c|c|c|c|c|}
\hline \multirow[b]{2}{*}{ Markers } & \multirow[b]{2}{*}{ Specificity } & \multirow{2}{*}{$\begin{array}{l}\text { Investigator criteria for } \\
\text { positive staining }\end{array}$} & \multicolumn{2}{|c|}{ Investigator $\mathrm{A}$ and $\mathrm{B}$ agreement } \\
\hline & & & $\begin{array}{c}\text { Significance level of } \\
\text { correlation }(r) \text { between } \\
\text { investigators }\end{array}$ & $\begin{array}{l}\text { 95\% CI of difference } \\
\text { between investigators }\end{array}$ \\
\hline RPE65 & Differentiated cells (cytosol/membrane) & Stained cytosol & $P<0.001$ & $-0.1 \%$ to $+0.0 \%$ \\
\hline PCNA & Proliferating cells (nucleus) & Stained nucleus & $P<0.001$ & $-3.3 \%$ to $+0.8 \%$ \\
\hline Caspase-3 & Apoptotic cells (mainly cytosol) & Stained cytosol & $P=0.044$ & $-0.2 \%$ to $+0.0 \%$ \\
\hline
\end{tabular}

CI: confidence interval; $r$ : Pearson's correlation coefficient.

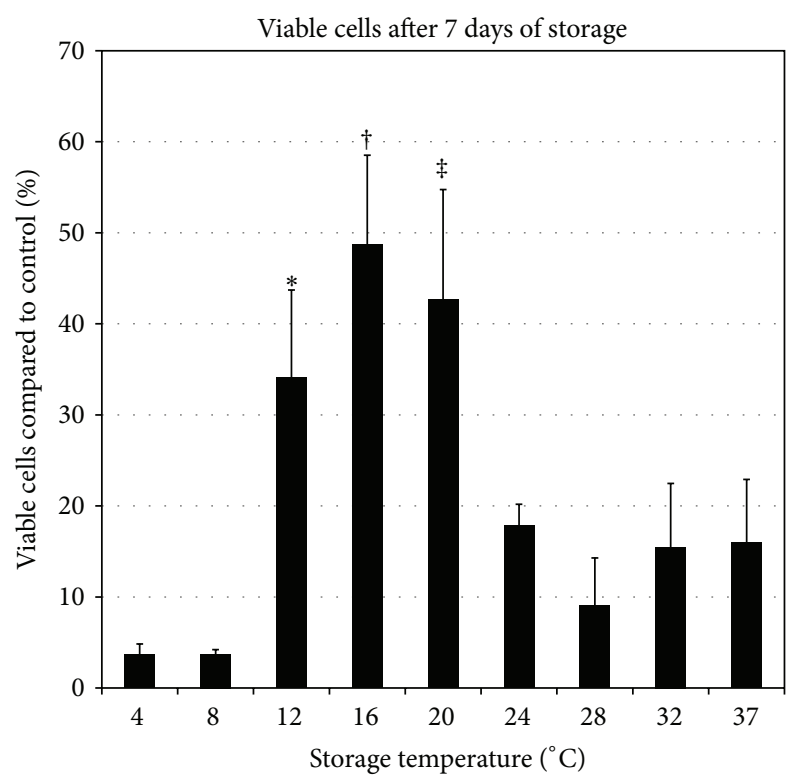

Figure 4: Cultured RPE cells were stored for seven days at $4^{\circ} \mathrm{C}$, $8^{\circ} \mathrm{C}, 12^{\circ} \mathrm{C}, 16^{\circ} \mathrm{C}, 20^{\circ} \mathrm{C}, 24^{\circ} \mathrm{C}, 28^{\circ} \mathrm{C}, 32^{\circ} \mathrm{C}$, and $37^{\circ} \mathrm{C}$, and viability was assessed with a calcein-acetoxymethyl ester reagent. The bar chart shows the percentage of viable cells after storage compared to control cells $(100 \%) .{ }^{*} \mathrm{P}<0.01$ compared to $4^{\circ} \mathrm{C}, 8^{\circ} \mathrm{C}, 28^{\circ} \mathrm{C}$, and $37^{\circ} \mathrm{C}$; $P<0.05$ compared to $24^{\circ} \mathrm{C}$ and $32^{\circ} \mathrm{C} .{ }^{\dagger} \mathrm{P}<0.01$ compared to $4^{\circ} \mathrm{C}, 8^{\circ} \mathrm{C}$, and $24^{\circ} \mathrm{C}-37^{\circ} \mathrm{C} ; P<0.05$ compared to $12^{\circ} \mathrm{C}$. ${ }^{\ddagger} P<0.01$ compared to $4^{\circ} \mathrm{C}, 8^{\circ} \mathrm{C}$, and $24^{\circ} \mathrm{C}-37^{\circ} \mathrm{C}$. Error bars represent the standard deviation of mean values.

of storage, as indicated by the CAM fluorescence measurements, was reduced at all storage temperatures compared to the control (Figure 4). Storage at $16^{\circ} \mathrm{C}$ conserved the highest number of live cells $\left(48.7 \% \pm 9.8 \% ; P<0.01\right.$ compared to $4^{\circ} \mathrm{C}$, $8^{\circ} \mathrm{C}$, and $24^{\circ} \mathrm{C}-37^{\circ} \mathrm{C} ; P<0.05$ compared to $12^{\circ} \mathrm{C}$ ). Twenty degrees storage conserved $42.7 \% \pm 12.1 \%$ of live cells $(P<$ 0.01 compared to $4^{\circ} \mathrm{C}, 8^{\circ} \mathrm{C}$, and $24^{\circ} \mathrm{C}-37^{\circ} \mathrm{C}$ ), while storage at $12^{\circ} \mathrm{C}$ conserved $34.2 \% \pm 9.6 \%$ of viable cells $(P<0.01$ compared to $4^{\circ} \mathrm{C}, 8^{\circ} \mathrm{C}, 28^{\circ} \mathrm{C}$, and $37^{\circ} \mathrm{C} ; P<0.05$ compared to $24^{\circ} \mathrm{C}$ and $32^{\circ} \mathrm{C}$ ). Thus, the temperatures $16^{\circ} \mathrm{C}$ and $20^{\circ} \mathrm{C}$ were superior for cell survival.

3.2. Morphology of Cultured ARPE-19 Cells following Storage. Scanning electron microscopy was performed to investigate the effect of storage temperature on the ultrastructure of cultured RPE cells. Prior to storage, the cells were generally well apposed and displayed an epithelial morphology (Figures 5(a)-5(b)). After storage, the ultrastructure was best maintained in the $12^{\circ} \mathrm{C}, 16^{\circ} \mathrm{C}$ and $20^{\circ} \mathrm{C}$, groups (Figures $5(\mathrm{~g}$ )5(l)). Cell-cell contact was mostly preserved at these three temperatures, although some intercellular spacing was seen. There were only occasional cells with apoptotic morphology (Figures $5(\mathrm{~g})-5(\mathrm{l}))$. After storage at temperatures below $12^{\circ} \mathrm{C}$ and above $20^{\circ} \mathrm{C}$, on the other hand, the majority of the remaining cells showed signs of cell damage and apoptosis. These signs included extensive loss of cell-cell contact, cell detachment, shrinkage, and membrane blebbing (Figures $5(\mathrm{c})-5(\mathrm{f})$ and $5(\mathrm{~m})-5(\mathrm{t}))$. Apical microvilli were found in control cultures and cultures stored at $12^{\circ} \mathrm{C}, 16^{\circ} \mathrm{C}$, and $20^{\circ} \mathrm{C}$, while few to no microvilli were found in cells stored at other temperatures (Figure 6). Collectively, these results were in agreement with the viability data, showing best cell preservation at $12^{\circ} \mathrm{C}, 16^{\circ} \mathrm{C}$, and $20^{\circ} \mathrm{C}$.

3.3. Phenotype of Cultured ARPE-19 Cells following Storage. To assess the effect of storage temperature on the phenotype of cultured RPE, cells stored at $12^{\circ} \mathrm{C}, 16^{\circ} \mathrm{C}$, and $20^{\circ} \mathrm{C}$ were immunostained with five different markers. Alexa Fluor 568 phalloidin staining was used for selective labeling of F-actin in order to visualize the cytoskeleton and assess the formation of stress fibers [27]. Actin staining revealed that the control cultures were the most heterogeneous, exhibiting actin arranged in stress fibers in some cells and circumferentially in others. Cultures stored at $12^{\circ} \mathrm{C}, 16^{\circ} \mathrm{C}$, and $20^{\circ} \mathrm{C}$ predominantly expressed circumferential actin arrangement and fewer elongated cells than the control cultures (Figure 7(a)).

To assess the integrity of the intercellular junctions, an anti-ZO-1 antibody was used. The antibody localized to cell borders and was present between all apposed cells. It revealed a predominance of polygonal cells in all groups, with a few elongated cells present only in the control cultures (Figure 7(b)).

Anti-RPE65 was used to detect RPE65, a protein crucial for the regeneration of visual pigment (Figure $7(\mathrm{c}))[7,31]$. RPE65 expression was demonstrated in $99.7 \% \pm 0.5 \%$ of control cells and in all cells following storage at $12^{\circ} \mathrm{C}, 16^{\circ} \mathrm{C}$, and $20^{\circ} \mathrm{C}(100 \% ; P=0.52$ compared to control) (Figure 7(d)).

An anti-PCNA antibody was employed to detect proliferating cells (Figure $7(\mathrm{e})$ ). The percentage of PCNA+ cells in the control was $12.3 \% \pm 4.2 \%$ (Figure $7(\mathrm{f})$ ). The expression level was maintained after storage at $12^{\circ} \mathrm{C}(17.3 \% \pm 5.4 \% ; P=0.73)$ 


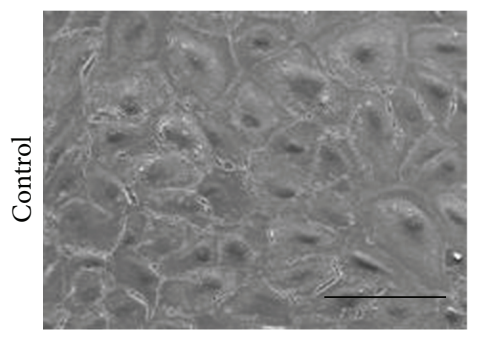

(a)

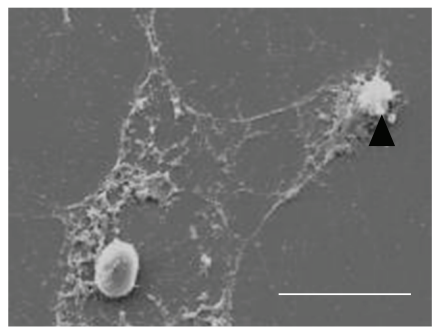

(d)

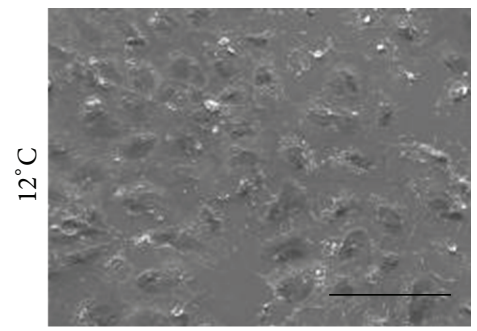

(g)

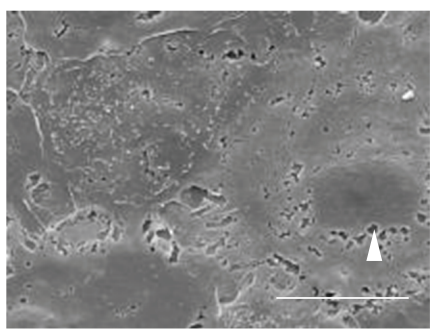

(j)

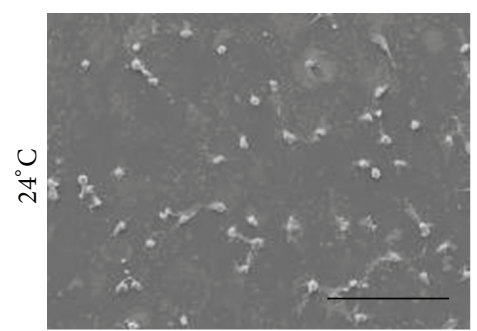

(m)

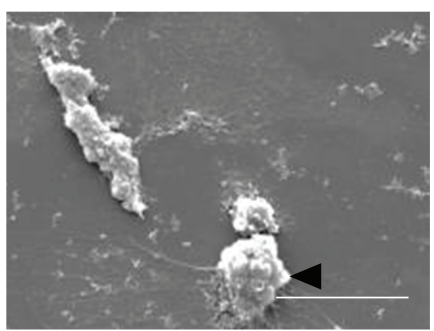

(p)

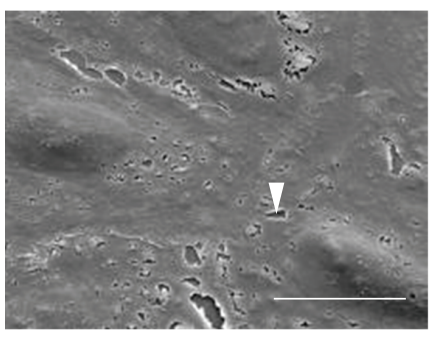

(b)

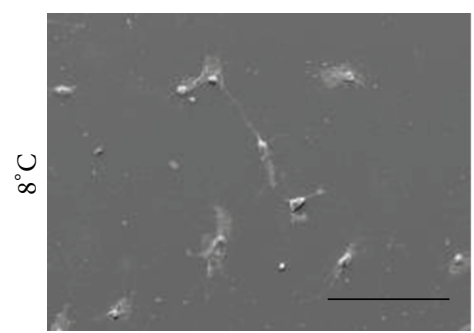

(e)

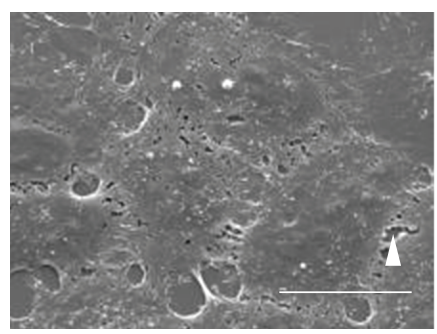

(h)

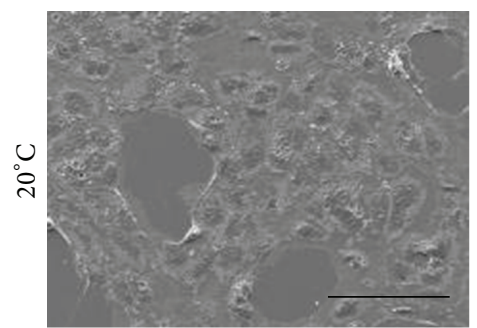

(k)

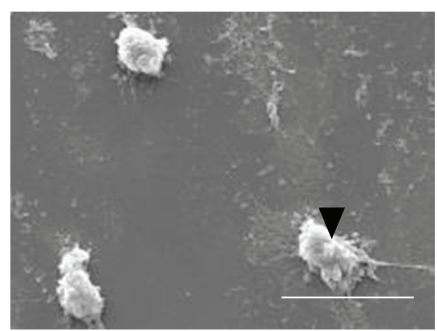

(n)

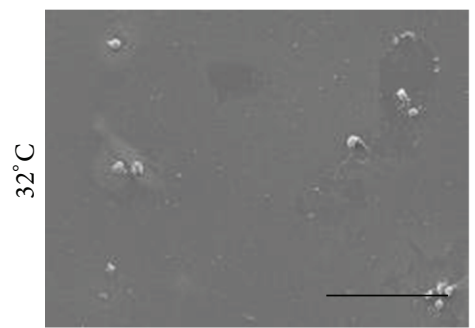

(q)

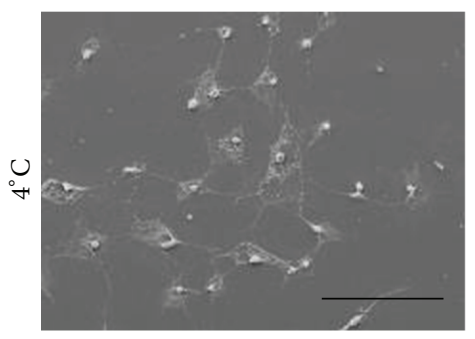

(c)

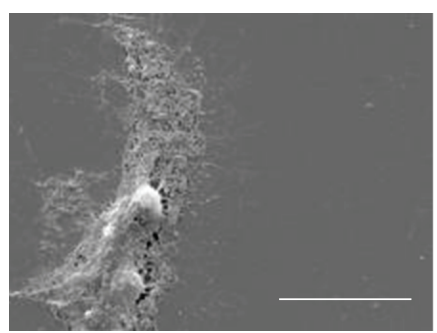

(f)

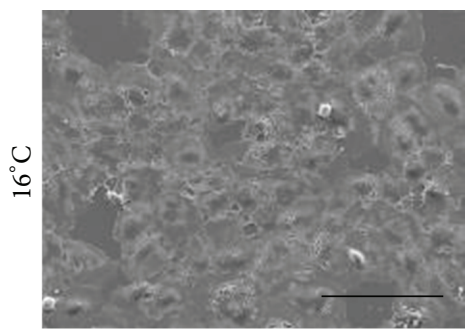

(i)

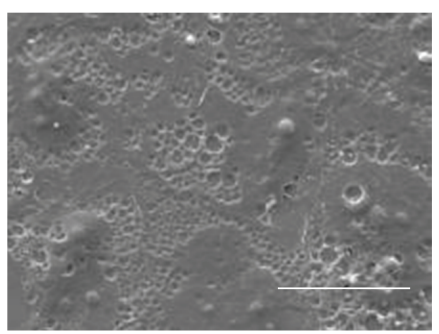

(1)

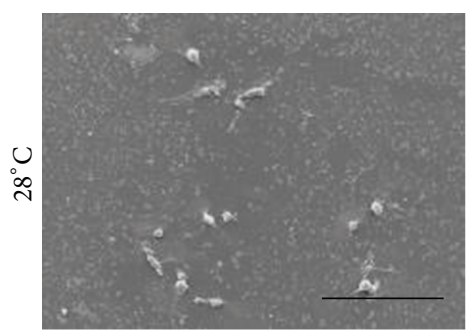

(o)

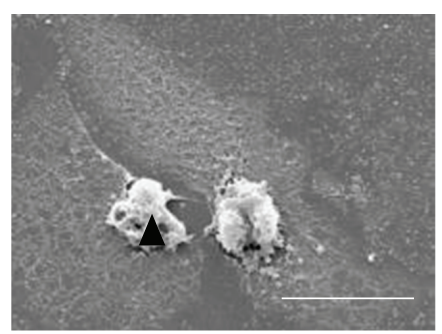

(r)

FIGURE 5: Continued. 


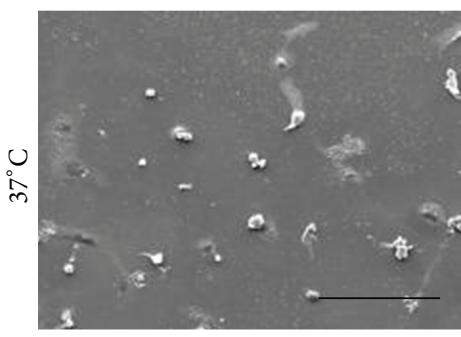

$(\mathrm{s})$

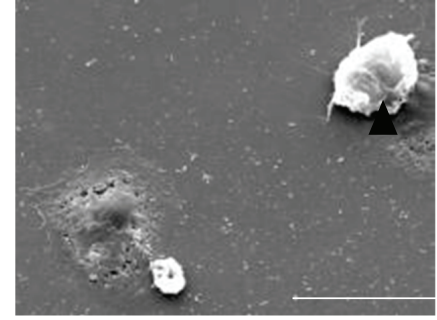

$(\mathrm{t})$

Figure 5: Photomicrographs of control cells and cells stored for seven days at $4^{\circ} \mathrm{C}, 8^{\circ} \mathrm{C}, 12^{\circ} \mathrm{C}, 16^{\circ} \mathrm{C}, 20^{\circ} \mathrm{C}, 24^{\circ} \mathrm{C}, 28^{\circ} \mathrm{C}, 32^{\circ} \mathrm{C}$, and $37^{\circ} \mathrm{C}$ were captured by a scanning electron microscope. An epithelial cobblestone morphology can be seen in the control ((a), (b)), and this was best maintained after storage at $12^{\circ} \mathrm{C}, 16^{\circ} \mathrm{C}$, and $20^{\circ} \mathrm{C}((\mathrm{g})-(\mathrm{l}))$. The cells demonstrate apoptotic morphological alterations like shrinkage and membrane blebbing after storage at temperatures below $12^{\circ} \mathrm{C}((\mathrm{c})-(\mathrm{f}))$ and above $20^{\circ} \mathrm{C}((\mathrm{m})-(\mathrm{t}))$. Images are representative of three independent samples. Scale bars: $100 \mu \mathrm{m}$ (black), $20 \mu \mathrm{m}$ (white). Black arrowheads: shrinkage and membrane blebbing. White arrowheads: microcracks representing artifacts due to sample preparation.
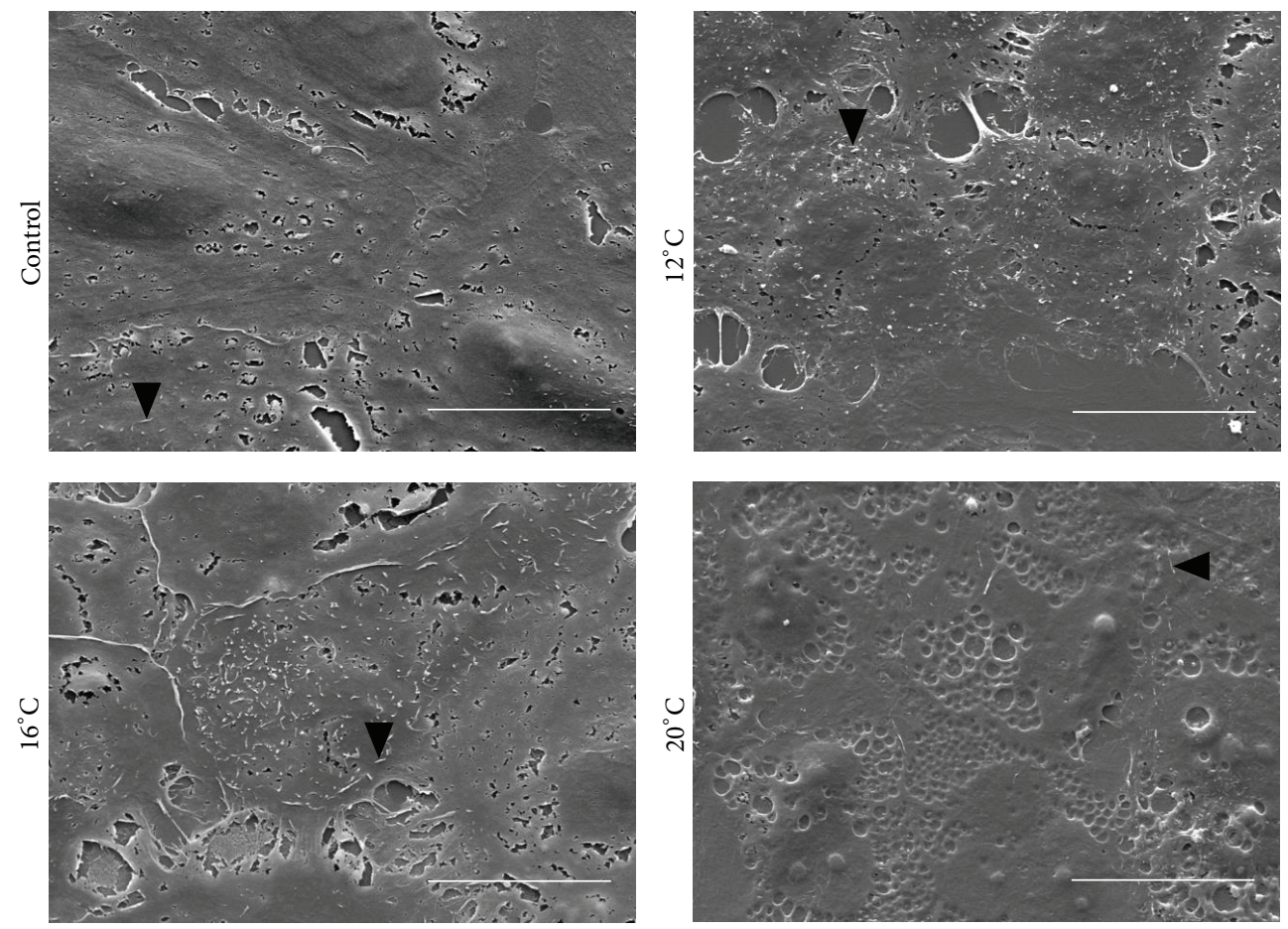

FIGURE 6: Scanning electron photomicrographs showing apical microvilli on control ARPE-19 cells as well as on cells subjected to seven days of storage at $12^{\circ} \mathrm{C}, 16^{\circ} \mathrm{C}$, and $20^{\circ} \mathrm{C}$. Scale bars: $20 \mu \mathrm{m}$. Black arrowheads: microvillus.

and $16^{\circ} \mathrm{C}(22.5 \% \pm 11.1 \% ; P=0.21)$ and increased after storage at $20^{\circ} \mathrm{C}(27.8 \% \pm 4.1 \% ; P=0.03)$.

To assess the percentage of dead cells, the cultures were immunostained with anti-caspase-3, an indicator of apoptosis (Figure $7(\mathrm{~g})$ ). As expected, the control cultures showed very few caspase- $3+$ cells $(0.09 \% \pm 0.18 \%)$ (Figure $7(\mathrm{~h}))$. The percentage of caspase- $3+$ cells did not increase after sevenday storage at $12^{\circ} \mathrm{C}(0.12 \% \pm 0.14 \% ; P=0.98), 16^{\circ} \mathrm{C}(0.05 \% \pm$ $0.09 \% ; P=0.96)$, or $20^{\circ} \mathrm{C}(0.02 \% \pm 0.04 \% ; P=0.86)$. These results support the morphology analyses that demonstrated only infrequent cells with apoptotic features in the $12^{\circ} \mathrm{C}, 16^{\circ} \mathrm{C}$, and $20^{\circ} \mathrm{C}$ groups.

\section{Discussion}

The present study shows that storage temperature has a crucial impact on the morphology and viability of cultured $\mathrm{RPE}$ cells. The storage temperature interval $12^{\circ} \mathrm{C}$ to $20^{\circ} \mathrm{C}$ was superior in preserving cell viability, morphology and phenotype.

Maintaining cell viability before transplantation is critically important for optimal graft survival and function. In ophthalmology, the technique of tissue preservation is mostly utilized for storage of corneas in eye banks. Corneas are either cold-stored at $4^{\circ} \mathrm{C}$ or organ cultured at $31-37^{\circ} \mathrm{C}$ [32]. 


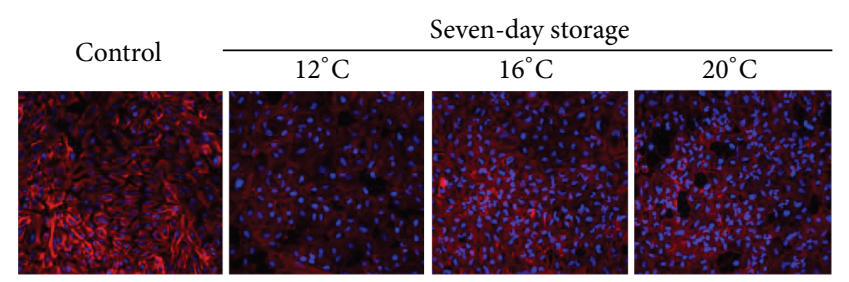

(a)

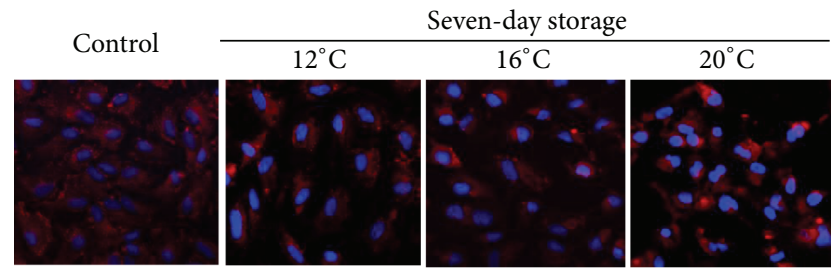

(c)

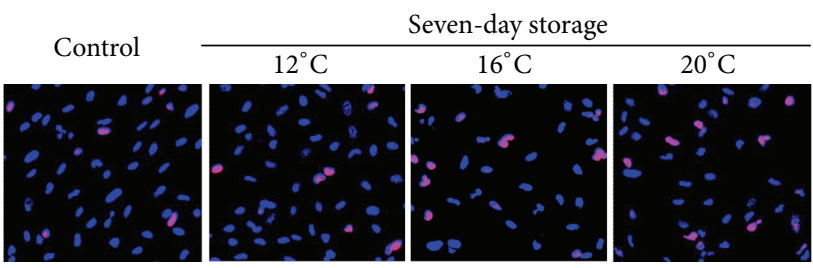

(e)

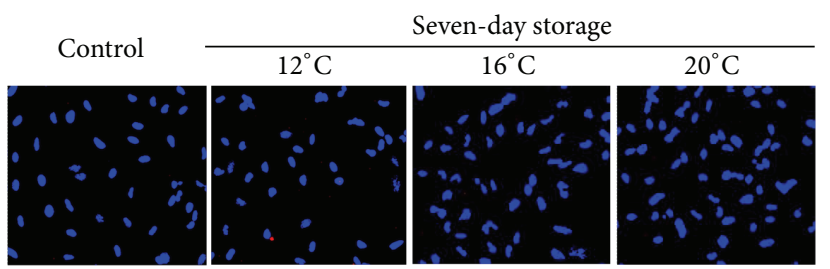

(g)

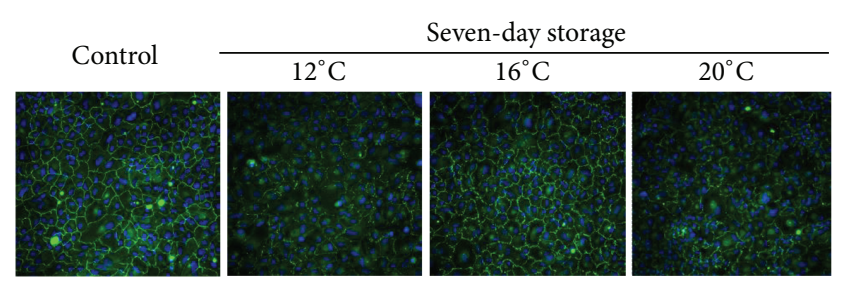

(b)

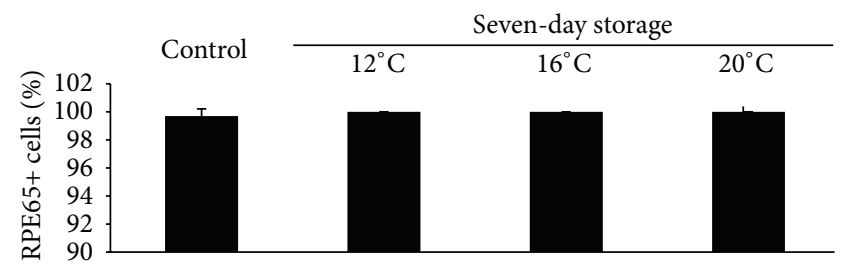

(d)

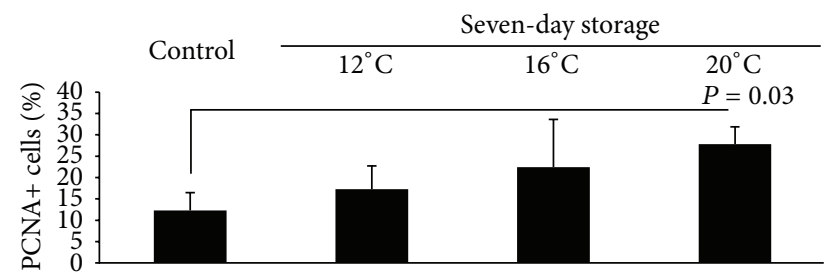

(f)

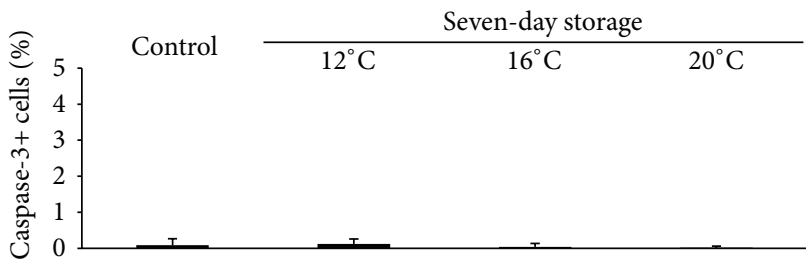

(h)

FIgURE 7: Cultured RPE cells were stored at $12^{\circ} \mathrm{C}, 16^{\circ} \mathrm{C}$, and $20^{\circ} \mathrm{C}$ for seven days, and expression of actin, ZO-1, RPE65, PCNA, and caspase-3 was assessed. The percentage of cells expressing RPE65, PCNA, and caspase- 3 was quantified by two independent and blinded investigators. (a) Photomicrographs showing immunostaining with phalloidin-Alexa 568 used to visualize actin filaments (red). Nuclei were stained with DAPI (blue). Original magnification: $\times 200$. (b) Photomicrographs showing immunostaining of ZO-1 (green). Nuclei were stained with DAPI (blue). Original magnification: $\times 200$. (c) Photomicrographs showing immunostaining of RPE65 (red). Nuclei were stained with DAPI (blue). Original magnification: $\times 200$. (d) Bar chart demonstrating RPE65 expression in stored and control cells. Expression of RPE65 was maintained after storage at all three temperatures. Error bars: standard deviation of mean values. (e) Photomicrographs showing immunostaining of PCNA (red) in control and stored cells. Nuclei were stained with DAPI (blue). Original magnification: $\times 200$. (f) Bar chart displaying the percentage of PCNA+ cells in the control cultures and in the storage groups. PCNA expression was maintained at $12^{\circ} \mathrm{C}$ and $16^{\circ} \mathrm{C}$ and increased after storage at $20^{\circ} \mathrm{C}$ compared to the control. Error bars: standard deviation of mean values. (g) Photomicrographs of cells stained with anticaspase-3 antibody (red). Nuclei were stained with DAPI (blue). Original magnification: $\times 200$. (h) Bar chart showing the percentage of caspase-3+ cells. There was no increase in caspase-3+ cells after storage compared to control. Error bars: standard deviation of mean values.

However, it is questionable whether these temperatures are optimal for maintaining RPE cell quality. In the present study we demonstrated that storage at $16^{\circ} \mathrm{C}$ and $20^{\circ} \mathrm{C}$ maintained the largest amount of live cells and moreover provided far superior results than cold conditions. The viability of adult primary RPE cell sheet grafts after storage has previously been investigated by Tezel and coworkers using a calcein and ethidium homodimer viability kit [33]. This group used cell counting rather than a microplate fluorometer. In that study, the ratio of live cells to the total cell number decreased to $32.4 \%$ after four days of storage at $4^{\circ} \mathrm{C}$. In the current study, we stored the cells for seven days instead of four, and in line with the study by Tezel and coworkers, the $4^{\circ} \mathrm{C}$ storage group showed a great drop in the number of live CAM-retaining cells compared to the control. It should be noted that we compared the number of live cells after storage with the number of live cells in the control, whereas Tezel and coworkers compared the ratio of live cells to the total cell number in the stored cultures. However, both of these studies suggest that $4^{\circ} \mathrm{C}$ is not the optimal temperature for RPE cell storage. The intriguing finding of the current study, that the best storage temperature for cultured RPE cells is 
approximately midway between the traditional temperatures for cell culture $\left(37^{\circ} \mathrm{C}\right)$ and cold storage $\left(4^{\circ} \mathrm{C}\right)$, is supported by studies on other epithelial cell types. Raeder and associates reported that the storage of cultured human limbal epithelial cells at $23^{\circ} \mathrm{C}$ is superior to storage at both $5^{\circ} \mathrm{C}$ and $31^{\circ} \mathrm{C}$ [20], while another study reported that cultured human conjunctival epithelium maintained viability after four days of storage at $23^{\circ} \mathrm{C}$ in HEPES-MEM [23]. Hypothermia has been shown to reduce both ARPE-19 cell metabolism and vascular endothelial growth factor secretion in a temperaturedependent fashion [34]. We speculate that the temperature decrease to $16^{\circ} \mathrm{C}$ halts ARPE-19 cell metabolism to such an extent that cell survival is improved compared to higher temperatures.

The ARPE-19 cell line used in the current study showed an epithelial morphology similar to that demonstrated previously with subcultures of this cell line [24]. Storing the cells at temperatures between $12^{\circ} \mathrm{C}$ and $20^{\circ} \mathrm{C}$ ensured the best preservation of ultrastructure, although increased intercellular spacing was seen after storage at all temperatures. Some of the intercellular gaps, however, represented microcracks due to critical point drying as part of sample preparation for scanning electron microscopy [35]. Apical microvilli, which have been demonstrated in ARPE-19 previously [31], have been reported to decrease in number in aging RPE cells [36]. The loss of apical microvilli causes unfavorable effects on the RPE cell functions and may accelerate degenerative processes in the retina $[36,37]$. Hence, our results showing the preservation of microvilli only at a specific temperature range further emphasizes the need for careful temperature control during RPE cell storage.

The actin cytoskeleton is involved in many cellular functions, affecting cell adhesion, morphogenesis, and phagocytosis [38]. Stress fibers are contractile bundles of actomyosin that are assembled when cells encounter mechanical stress [38]. Their presence in vivo is usually confined to muscle cells and myofibroblasts in dermal wound tissue [39], but they are common in epithelial cells cultured in vitro [39]. Formation of actin stress fibers in the ARPE-19 cell line has been reported earlier, and it has been demonstrated that the cells' propensity for developing these fibers depends both on culture length and the composition of the culture medium [27]. To ensure that the ARPE-19 cells used in the present study displayed normal epithelial characteristics, the actin cytoskeleton was visualized with phalloidin-Alexa 568. The staining revealed that, prior to storage, the actin filaments were mostly arranged in circumferential bands but that a subset of cells were elongated and displayed stress fiber formation. After storage at $12^{\circ} \mathrm{C}, 16^{\circ} \mathrm{C}$, and $20^{\circ} \mathrm{C}$, actin staining revealed no stress fiber formation, indicating both preservation and promotion of normal epithelial characteristics of ARPE-19 cells stored in serum-free HEPES-MEM. In support of this finding, Luo et al. [27] have reported a reduced tendency of stress fiber formation in ARPE-19 cells cultured in serum-free medium when compared to cells cultured in serum-supplemented medium.

To assess the presence of intercellular tight junctions, staining with anti-ZO-1 antibody was performed. The marker localized to cell borders and was present between all apposed cells, indicating a tight junction organization typical of native RPE and revealing a cobblestone morphology with a predominance of polygonal cells in all groups (Figure 7(b)).

Compared with the control, we did not detect a different RPE expression profile following storage at $12^{\circ} \mathrm{C}, 16^{\circ} \mathrm{C}$, and $20^{\circ} \mathrm{C}$. The RPE65 protein is considered an essential marker of RPE cell differentiation [31]. Even though the ATCC recommends a FBS-containing culture medium [40], storage of ARPE-19 cells in serum-free HEPES-MEM did not apparently affect the expression of the differentiation marker RPE65.

Proliferating cell nuclear antigen (PCNA) expression was maintained after storage at $12^{\circ} \mathrm{C}$ and $16^{\circ} \mathrm{C}$ but increased after storage at $20^{\circ} \mathrm{C}$. Maintenance of PCNA expression during storage has also been reported for cultured human conjunctival epithelium kept for seven days at $23^{\circ} \mathrm{C}$ in HEPESMEM [23]. According to Rieder and Cole, transition through the $G_{2}$ and $M$ phases of mitosis comes to a halt when the temperature is lowered to approximately $16-20^{\circ} \mathrm{C}$, thereby prolonging the cell cycle [41]. The tendency for a progressively decreasing percentage of PCNA+ cells with lower storage temperature in our study could be related to the inhibited $\mathrm{G}_{2} / \mathrm{M}$ transition below $16-20^{\circ} \mathrm{C}$. Upon heating, cells that have been stored at $19^{\circ} \mathrm{C}$ proliferate at an even higher rate than that of control cells maintained at $37^{\circ} \mathrm{C}$ [41]. The RPE cell layer is mitotically inactive in vivo [42], but has the ability to grow by cell enlargement if damage occurs $[6,42]$. Both transplanted freshly harvested RPE and transplanted cultured RPE are capable of proliferating in vivo, but proliferation is halted upon close apposition to the neural retina, indicating an effect of the neural retina in stalling RPE cell proliferation [43]. Thus, it can be expected that the stored RPE cells will eventually stop dividing following transplantation. Some initial proliferative activity may be advantageous, as it could enable transplanted cells to cover exposed areas of Bruch's membrane [33, 44].

In the present study, we did not detect an increase in caspase-3+ apoptotic cells after storage. However, the number of CAM+ live cells after storage dropped to less than $50 \%$ compared to the control. The low percentage of caspase- $3+$ cells can be explained by the dead cells' tendency to detach and be washed away during rinsing prior to immunostaining. In support of this assumption, we found very few cells demonstrating an apoptotic morphology after storage at $12^{\circ} \mathrm{C}$, $16^{\circ} \mathrm{C}$, and $20^{\circ} \mathrm{C}$.

Several laboratories have investigated the cultivation of RPE cells on artificial substrates, aiming to identify carrier materials that could be directly transplanted into the subretinal space $[15,45,46]$. However, there is currently no consensus in regard to the future use of culture substrates for RPE transplantation. In the current study, ARPE-19 cells were cultured on glass or plastic culture dishes, reducing the culture variables to a minimum and allowing the impact of storage temperature on cultured cell sheets to be isolated. In support of this study design, it has been shown that differences in the ARPE-19 transcriptome can be attributed to culture conditions and that culturing of ARPE-19 cells on plastic substrates is superior in maintaining a phenotype closest to native RPE cells [47]. A storage period of seven 
days should be sufficient time to allow transportation from the culture laboratories to the clinics, sterility control, and preparation for the transplantation procedure. Furthermore, a major advantage of the current storage method is the ability for cell preservation without $\mathrm{CO}_{2}$ incubation, thereby facilitating transportation. The methods used in the current study are, however, not directly clinically applicable, and further studies on the validation of our storage technique using clinically applicable RPE cell sources and carrier substrates are warranted. Future studies aimed at identifying storage conditions and specific growth stimulating factors for RPE cell maintenance could further refine the technology to improve cell survival following storage.

\section{Conclusion}

In conclusion, this study demonstrates that human cultured $\mathrm{RPE}$ cells are best preserved at the temperature range $12^{\circ} \mathrm{C}$ to $20^{\circ} \mathrm{C}$. The capability to preserve RPE cells is essential for the future advancement of RPE cell replacement therapy. Moreover, the storage method described in the current study may be applicable for other cell types and tissues; thus its significance may extend well beyond RPE and eye diseases.

\section{Conflict of Interests}

The authors declare no conflict of interests.

\section{Acknowledgments}

The authors thank Steinar Stølen at the Department of Oral Biology, Faculty of Dentistry, the University of Oslo, for excellent assistance with scanning electron microscopy. The authors would also like to thank Roger Eidet for exceptional technological contribution.

\section{References}

[1] R. D. Lund, P. Adamson, Y. Sauvé et al., "Subretinal transplantation of genetically modified human cell lines attenuates loss of visual function in dystrophic rats," Proceedings of the National Academy of Sciences of the United States of America, vol. 98, no. 17, pp. 9942-9947, 2001.

[2] T. J. McGill, R. D. Lund, R. M. Douglas, S. Wang, B. Lu, and G. T. Prusky, "Preservation of vision following cell-based therapies in a model of retinal degenerative disease," Vision Research, vol. 44, no. 22, pp. 2559-2566, 2004.

[3] A. Carr, A. A. Vugler, S. T. Hikita et al., "Protective effects of human iPS-derived retinal pigment epithelium cell transplantation in the retinal dystrophic rat," PLoS ONE, vol. 4, no. 12, Article ID e8152, 2009.

[4] K. Bharti, S. S. Miller, and H. Arnheiter, "The new paradigm: retinal pigment epithelium cells generated from embryonic or induced pluripotent stem cells," Pigment Cell and Melanoma Research, vol. 24, no. 1, pp. 21-34, 2011.

[5] C. M. Sheridan, S. Mason, D. M. Pattwell, D. Kent, I. Grierson, and R. Williams, "Replacement of the RPE monolayer," Eye, vol. 23, no. 10, pp. 1910-1915, 2009.
[6] N. Yaji, M. Yamato, J. Yang, T. Okano, and S. Hori, “Transplantation of tissue-engineered retinal pigment epithelial cell sheets in a rabbit model," Biomaterials, vol. 30, no. 5, pp. 797-803, 2009.

[7] H. Vaajasaari, T. Ilmarinen, K. Juuti-Uusitalo et al., "Toward the defined and xeno-free differentiation of functional human pluripotent stem cell-derived retinal pigment epithelial cells," Molecular Vision, vol. 17, pp. 558-575, 2011.

[8] C. I. Falkner-Radler, I. Krebs, C. Glittenberg et al., "Human retinal pigment epithelium (RPE) transplantation: outcome after autologous RPE-choroid sheet and RPE cell-suspension in a randomised clinical study," British Journal of Ophthalmology, vol. 95, no. 3, pp. 370-375, 2011.

[9] T. Zhang, Y. Hu, Y. Li et al., "Photoreceptors repair by autologous transplantation of retinal pigment epithelium and partialthickness choroid graft in rabbits," Investigative Ophthalmology and Visual Science, vol. 50, no. 6, pp. 2982-2988, 2009.

[10] P. J. Coffey, S. Girman, S. M. Wang et al., "Long-term preservation of cortically dependent visual function in RCS rats by transplantation," Nature Neuroscience, vol. 5, no. 1, pp. 53-56, 2002.

[11] S. Wang, B. Lu, P. Wood, and R. D. Lund, "Grafting of ARPE19 and Schwann cells to the subretinal space in RCS rats," Investigative Ophthalmology and Visual Science, vol. 46, no. 7, pp. 2552-2560, 2005.

[12] Y. Sauvé, I. Pinilla, and R. D. Lund, "Partial preservation of rod and cone ERG function following subretinal injection of ARPE19 cells in RCS rats," Vision Research, vol. 46, no. 8-9, pp. 1459$1472,2006$.

[13] Z. Ma, L. Han, C. Wang et al., "Autologous transplantation of retinal pigment epithelium-bruch's membrane complex for hemorrhagic age-related macular degeneration," Investigative Ophthalmology and Visual Science, vol. 50, no. 6, pp. 2975-2981, 2009.

[14] K. Ohno-Matsui, S. Ichinose, K. Nakahama et al., "The effects of amniotic membrane on retinal pigment epithelial cell differentiation," Molecular Vision, vol. 11, pp. 1-10, 2005.

[15] K. J. McHugh, C. Spencer, P. A. D’Amore, S. L. Tao, and M. SaintGeniez, "A porous poly( $\varepsilon$-caprolactone) tissue engineering scaffold for RPE transplantation," ARVO E-Abstract 3641, 2012.

[16] S. L. Mason, R. M. Stewart, V. R. Kearns, R. L. Williams, and C. M. Sheridan, "Ocular epithelial transplantation: current uses and future potential," Regenerative Medicine, vol. 6, no. 6, pp. 767-782, 2011.

[17] A. Chopdar, U. Chakravarthy, and D. Verma, "Age related macular degeneration," British Medical Journal, vol. 326, no. 7387, pp. 485-488, 2003.

[18] S. Ahmad, C. Osei-Bempong, R. Dana, and U. Jurkunas, "The culture and transplantation of human limbal stem cells," Journal of Cellular Physiology, vol. 225, no. 1, pp. 15-19, 2010.

[19] J. T. Daniels, G. A. Secker, A. J. Shortt, S. J. Tuft, and S. Seetharaman, "Stem cell therapy delivery: treading the regulatory tightrope," Regenerative Medicine, vol. 1, no. 5, pp. 715-719, 2006.

[20] S. Raeder, T. P. Utheim, Ø. A. Utheim et al., "Effects of organ culture and optisol-GS storage on structural integrity, phenotypes, and apoptosis in cultured corneal epithelium," Investigative Ophthalmology and Visual Science, vol. 48, no. 12, pp. 5484-5493, 2007.

[21] T. P. Utheim, S. Raeder, Ø. A. Utheim et al., "A novel method for preserving cultured limbal epithelial cells," British Journal of Ophthalmology, vol. 91, no. 6, pp. 797-800, 2007. 
[22] T. P. Utheim, S. Raeder, Ø. A. Utheim, M. de la Paz, B. Roald, and T. Lyberg, "Sterility control and long-term eye-bank storage of cultured human limbal epithelial cells for transplantation," British Journal of Ophthalmology, vol. 93, no. 7, pp. 980-983, 2009.

[23] J. R. Eidet, O. A. Utheim, S. Raeder et al., "Effects of serumfree storage on morphology, phenotype, and viability of exvivo cultured human conjunctival epithelium," Experimental Eye Research, vol. 94, no. 1, pp. 109-116, 2012.

[24] K. C. Dunn, A. E. Aotaki-Keen, F. R. Putkey, and L. M. Hjelmeland, "ARPE-19, a human retinal pigment epithelial cell line with differentiated properties," Experimental Eye Research, vol. 62, no. 2, pp. 155-169, 1996.

[25] K. C. Dunn, A. D. Marmorstein, V. L. Bonilha, E. RodriguezBoulan, F. Giordano, and L. M. Hjelmeland, "Use of the ARPE19 cell line as a model of RPE polarity: basolateral secretion of FGF5," Investigative Ophthalmology and Visual Science, vol. 39, no. 13, pp. 2744-2749, 1998.

[26] J. Tian, K. Ishibashi, S. Honda, S. A. Boylan, L. M. Hjelmeland, and J. T. Handa, "The expression of native and cultured human retinal pigment epithelial cells grown in different culture conditions," British Journal of Ophthalmology, vol. 89, no. 11, pp. 1510-1517, 2005.

[27] Y. Luo, Y. Zhuo, M. Fukuhara, and L. J. Rizzolo, "Effects of culture conditions on heterogeneity and the apical junctional complex of the ARPE-19 cell line," Investigative Ophthalmology and Visual Science, vol. 47, no. 8, pp. 3644-3655, 2006.

[28] C. A. Poole, N. H. Brookes, and G. M. Clover, "Keratocyte networks visualised in the living cornea using vital dyes," Journal of Cell Science, vol. 106, no. 2, pp. 685-692, 1993.

[29] S. Raeder, T. P. Utheim, Ø. A. Utheim et al., "Effect of limbal explant orientation on the histology, phenotype, ultrastructure and barrier function of cultured limbal epithelial cells," Acta Ophthalmologica Scandinavica, vol. 85, no. 4, pp. 377-386, 2007.

[30] T. Yue, C. Wang, A. M. Romanic et al., "Staurosporine-induced apoptosis in cardiomyocytes: a potential role of caspase-3," Journal of Molecular and Cellular Cardiology, vol. 30, no. 3, pp. 495-507, 1998.

[31] A. Ahmado, A. Carr, A. A. Vugler et al., "Induction of differentiation by pyruvate and DMEM in the human retinal pigment epithelium cell line ARPE-19," Investigative Ophthalmology \& Visual Science, vol. 52, no. 10, pp. 7148-7159, 2011.

[32] P. Elisabeth, B. Hilde, and C. Ilse, "Eye bank issues: II. Preservation techniques: warm versus cold storage," International Ophthalmology, vol. 28, no. 3, pp. 155-163, 2008.

[33] T. H. Tezel, L. V. del Priore, and H. J. Kaplan, "Harvest and storage of adult human retinal pigment epithelial sheets," Current Eye Research, vol. 16, no. 8, pp. 802-809, 1997.

[34] M. Coassin, K. G. Duncan, K. R. Bailey, A. Singh, and D. M. Schwartz, "Hypothermia reduces secretion of vascular endothelial growth factor by cultured retinal pigment epithelial cells," British Journal of Ophthalmology, vol. 94, no. 12, pp. 1678-1683, 2010.

[35] D. Cantu-Crouch, W. E. Howe, and M. D. McCartney, "Comparison of SEM processing methods for cultured human lens epithelial cells grown on flat and microcarrier bead substrates," Microscopy Research and Technique, vol. 30, no. 5, pp. 419-426, 1995.

[36] V. L. Bonilha, "Age and disease-related structural changes in the retinal pigment epithelium," Clinical Ophthalmology, vol. 2, no. 2, pp. 413-424, 2008.
[37] M. E. Rayborn, J. G. Hollyfield, and V. L. Bonilha, "Age-related changes in the retinal pigment epithelium apical surface," ARVO E-Abstract 3049, 2005.

[38] S. Tojkander, G. Gateva, and P. Lappalainen, "Actin stress fibers-assembly, dynamics and biological roles," Journal of Cell Science, vol. 125, no. 8, pp. 1855-1864, 2012.

[39] S. Pellegrin and H. Mellor, "Actin stress fibers," Journal of Cell Science, vol. 120, no. 20, pp. 3491-3499, 2007.

[40] The American Type Culture Collection, "Product description for CRL-2302," ATCC web site, http://www.lgcstandardsatcc.org/LGCAdvancedCatalogueSearch/ProductDescription/ tabid/1068/Default.aspx?ATCCNum $=$ CRL-2302\&Template $=$ ce llBiology.

[41] C. L. Rieder and R. W. Cole, "Cold-shock and the Mammalian cell cycle," Cell Cycle, vol. 1, no. 3, pp. 169-175, 2002.

[42] K. H. Leschey, S. F. Hackett, J. H. Singer, and P. A. Campochiaro, "Growth factor responsiveness of human retinal pigment epithelial cells," Investigative Ophthalmology and Visual Science, vol. 31, no. 5, pp. 839-846, 1990.

[43] H. Wang, D. S. Leonard, A. A. Castellarin et al., "Short-term study of allogeneic retinal pigment epithelium transplants onto debrided Bruch's membrane," Investigative Ophthalmology and Visual Science, vol. 42, no. 12, pp. 2990-2999, 2001.

[44] T. H. Tezel, "Reattachment to a substrate prevents apoptosis of human retinal pigment epithelium," Graefe's Archive for Clinical and Experimental Ophthalmology, vol. 235, no. 1, pp. 41-47, 1997.

[45] Y. Hu, L. Liu, B. Lu et al., "A novel approach for subretinal implantation of ultrathin substrates containing stem cellderived retinal pigment epithelium monolayer," Ophthalmic Research, vol. 48, no. 4, pp. 186-191, 2012.

[46] F. Thieltges, B. V. Stanzel, Z. Liu, and F. G. Holz, "A nanofibrillar surface promotes superior growth characteristics in cultured human retinal pigment epithelium," Ophthalmic Research, vol. 46, no. 3, pp. 133-140, 2011.

[47] J. Tian, K. Ishibashi, and J. T. Handa, "The expression of native and cultured RPE grown on different matrices," Physiological Genomics, vol. 17, no. 2, pp. 170-182, 2004. 


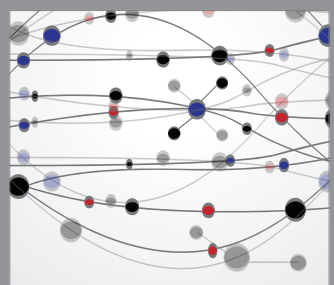

The Scientific World Journal
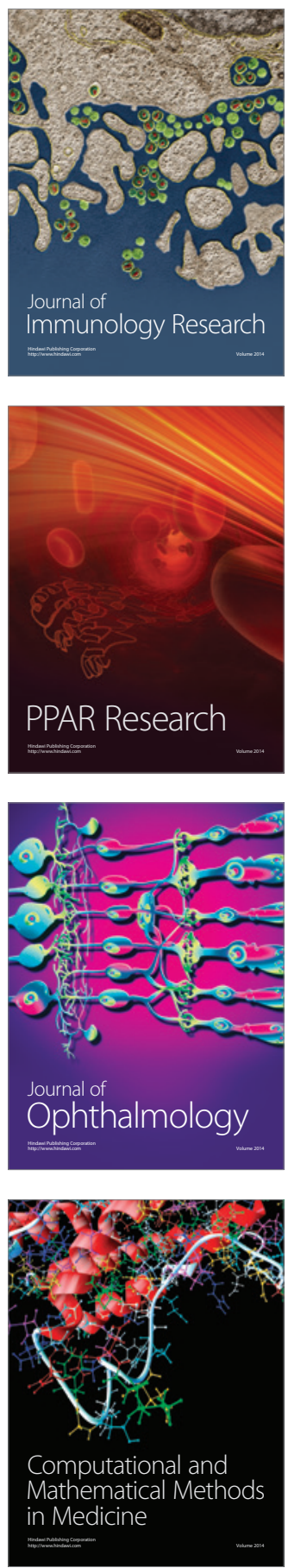

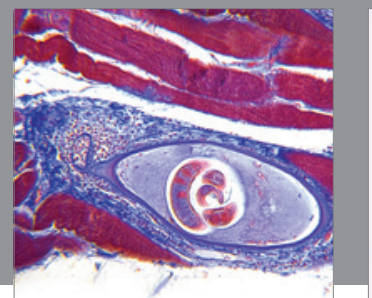

Gastroenterology

Research and Practice
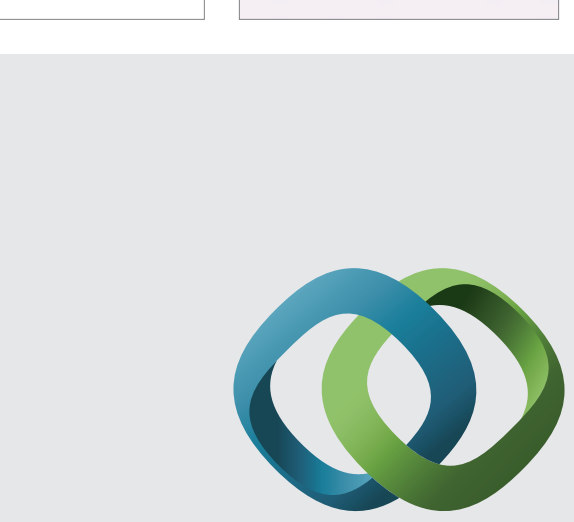

\section{Hindawi}

Submit your manuscripts at

http://www.hindawi.com
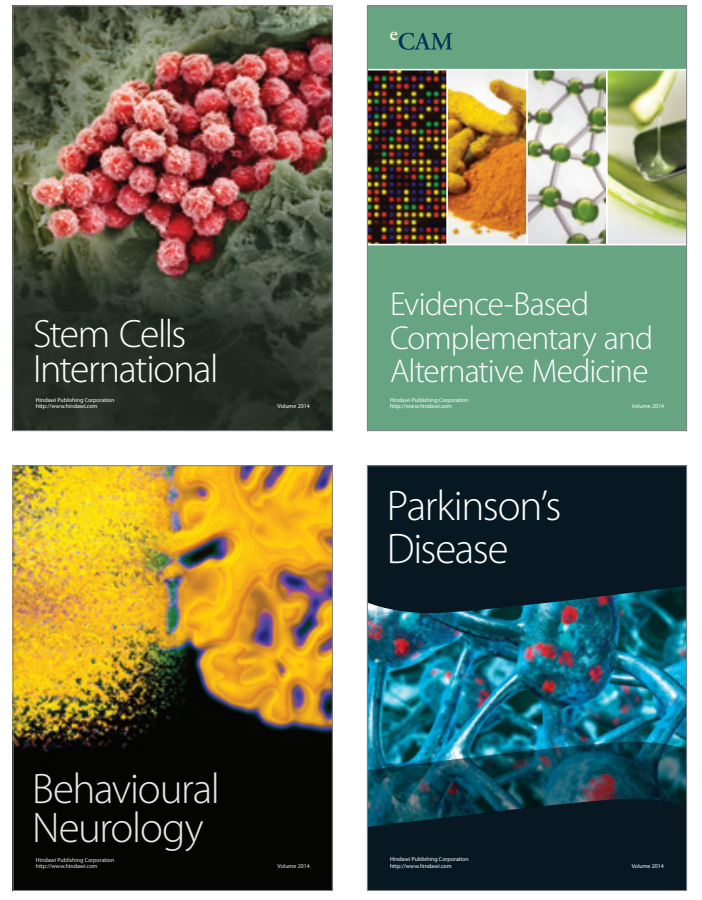
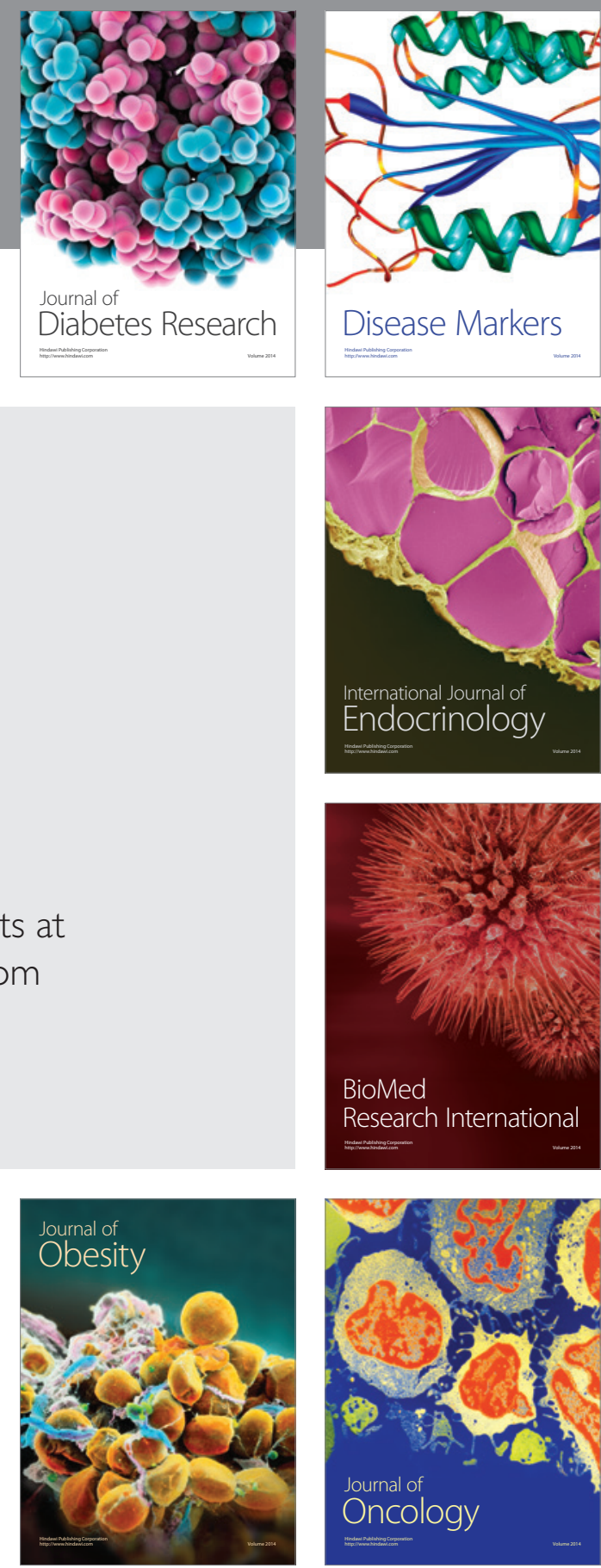

Disease Markers
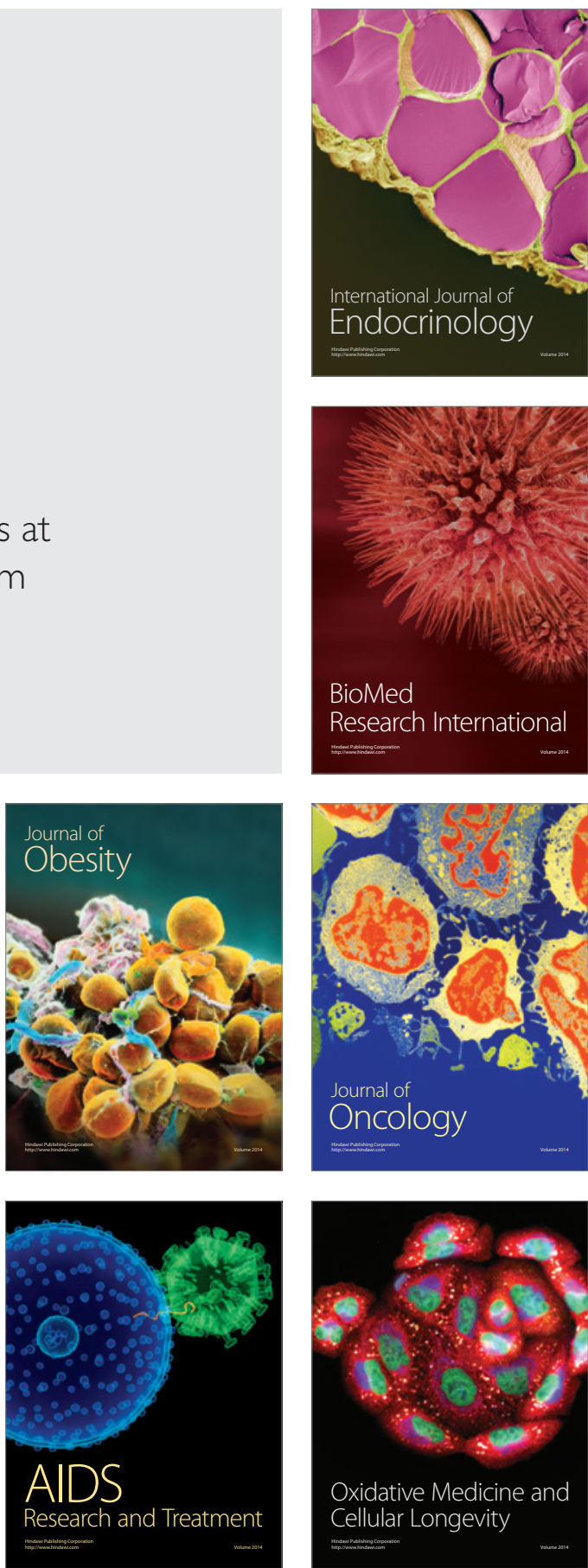